University of Nebraska - Lincoln

DigitalCommons@University of Nebraska - Lincoln

May 1984

\title{
TESTICULAR DEVELOPMENT AND ENDOCRINE CHARACTERISTICS OF BOARS SELECTED FOR EITHER HIGH OR LOW TESTIS SIZE
}

\author{
A. P. Schinckel \\ University of Nebraska-Lincoln \\ R. K. Johnson \\ University of Nebraska-Lincoln, rjohnson5@unl.edu \\ R. J. Kittock \\ University of Nebraska-Lincoln
}

Follow this and additional works at: https://digitalcommons.unl.edu/animalscifacpub

Part of the Animal Sciences Commons

Schinckel, A. P.; Johnson, R. K.; and Kittock, R. J., "TESTICULAR DEVELOPMENT AND ENDOCRINE CHARACTERISTICS OF BOARS SELECTED FOR EITHER HIGH OR LOW TESTIS SIZE " (1984). Faculty Papers and Publications in Animal Science. 84.

https://digitalcommons.unl.edu/animalscifacpub/84

This Article is brought to you for free and open access by the Animal Science Department at DigitalCommons@University of Nebraska - Lincoln. It has been accepted for inclusion in Faculty Papers and Publications in Animal Science by an authorized administrator of DigitalCommons@University of Nebraska - Lincoln. 


\title{
TESTICULAR DEVELOPMENT AND ENDOCRINE CHARACTERISTICS OF BOARS SELECTED FOR EITHER HIGH OR LOW TESTIS SIZE ${ }^{1}$
}

\author{
A. P. Schinckel ${ }^{2}$, R. K. Johnson ${ }^{3}$ and R. J. Kittok ${ }^{3}$ \\ University of Nebraska, Lincoln 68583
}

\section{Summary}

Thirty-six Landrace $x$ Large White cross boars were selected from litters with either high or low estimated breeding values for $150-\mathrm{d}$ paired testis weight. Blood samples were taken via jugular venipuncture at eight ages $(42,56$, $70,84,98,112,126$ and 140 d). At each sampling age, nine blood samples were taken at 30-min intervals. Luteinizing hormone (LH) was determined on the individual serum samples. Serum samples from each boar at each age were pooled and concentrations of follicle-stimulating hormone (FSH), estradiol- $17 \beta\left(\mathrm{E}_{2}\right)$ and testosterone $(T)$ were determined. Paired testis width, testis length and body weight were measured at 98,112, 126 and $140 \mathrm{~d}$ of age. Backfat probe, weights of excised testes and histological data on testes were obtained at 140 d of age. Boars with high testis weight (HTW) were heavier $(P<.05)$, had higher adjusted backfat probes $(\mathrm{P}<.01)$ and had consistently larger in situ testis measurements $(\mathrm{P}<.01)$ than did low testis weight (LTW) boars. Boars with HTW had heavier $(\mathrm{P}<.01)$ testes and epididymides at $140 \mathrm{~d}$ of age. They also had a higher percentage of seminiferous tubules in which spermatogenesis was present $(\mathrm{P}<.05)$, a larger percentage of tubules with a lumen $(P<.05)$ and tubules had a larger mean diameter $(P<.01)$ than did those of boars with LTW. Adjustment of in situ testis measurements and excised testis weights for body weight reduced line differences by less than $20 \%$. A rise in LH concentrations occurred at approximately $100 \mathrm{~d}$ of age. Boars with HTW had higher $(\mathrm{P}<.05)$ and more variable

\footnotetext{
${ }^{1}$ Published as Paper No. 7134 Journal Series, Nebraska Agr. Exp. Sta., Lincoln.

${ }^{2}$ Present address: Anim. Sci. Dept., Lilly Hall, Purdue Univ., West Lafayette, IN 47907.

${ }^{3}$ Anim. Sci. Dept., Univ. of Nebraska, Lincoln.

Received March 23, 1983.

Accepted August 19, 1983.
}

$(\mathrm{P}<.01)$ LH concentrations than did boars with LTW. Boars with HTW also had higher maximum concentrations of $\mathrm{LH}$ during the pubertal rise $(\mathrm{P}<.01)$ and these concentrations tended to reach maximum levels at younger ages. Concentrations of $T$ increased in a fashion that was nearly linear with age $(\mathrm{P}<.01)$ and tended to be higher for the boars with HTW $(P<.10)$. Concentrations of $E_{2}$ changed little from 42 to $84 \mathrm{~d}$ of age but increased steadily thereafter. Boars with HTW had a more rapid increase in $E_{2}$ concentrations than did boars with LTW $(\mathrm{P}<.05)$. Concentrations of $T$ and $E_{2}$ were similar for boars of the HTW and LTW groups after adjustment to a constant testis size. The results suggest that testis size will respond to selection in swine and that genetic changes in testis size are associated with changes in LH concentrations.

(Key Words: Swine, Testis Size, Luteinizing Hormone, Follicle-Stimulating Hormone, Testosterone, Estradiol-17 $\beta$.)

\section{Introduction}

Improved reproductive efficiency will increase overall efficiency of swine production. However, reproductive traits have low heritabilities and response to selection is expected to be slow. Rate of response to selection could be improved if a moderate to highly heritable trair of the boar could be used as an indicator of the reproductive efficiency of genetically related females. Land (1973) has suggested that testis size may fill this role.

A positive relationship between testis size and ovulation rate has been found in mice (Land, 1973; Islam et al., 1976; Joakimsen and Baker, 1977), sheep (Carr and Land, 1975; Hanrahan and Quirke, 1977) and swine (Schinckel et al., 1983). Heritabilities of intact testis dimensions and excised testis weight of boars have been estimated to be .58 and .77 , respectively (Legault et al., 1980). Islam et al. 
(1976) found a realized heritability of .52 for testis weight in mice and Land and Lee (1976) reported a realized heritability of .4 for testis size in rams.

Gonads of both sexes have similar hormonal control systems. Testicular development, spermatogenesis and steroid production in the male are controlled by follicle-stimulating hormone (FSH) and luteinizing hormone ( $\mathrm{LH}$ ); hormones that have parallel roles in controlling ovarian function. Evidence suggests that the same autosomal genes control these hormones in both sexes. Male and female mice from a line selected for high induced ovulation rate had increased gonadal sensitivity to FSH (Wolfe et al., 1981). Ewes and rams of the Finnish Landrace breed were less sensitive to negative feedback of steroids and had earlier pubertal releases of $\mathrm{LH}$ than did those of other, less prolific breeds (Land and Carr, 1975 ; Land and Lee, 1976).

Selection for testis size may alter endocrine systems such that reproductive performance will be improved. The objective of this study was to characterize testicular development and hormone concentrations of boars selected for either high or low testis size.

\section{Materials and Methods}

Thirty-six boars from the $F_{3}$ generation of a Landrace $x$ Large White composite population were selected from litters with either high or low estimated breeding values for $150-\mathrm{d}$ paired testis weight. From a total of 128 litters, 20 boars were chosen from the eight litters that had the highest estimated breeding value and 16 boars were chosen from the seven litters that had the lowest estimated breeding value. Testis weight was assumed to have a heritability of .5 and breeding values were estimated from records on the sire, the sire of the dam and two males that were full-sibs to the dam (Lush, 1948). Mean estimated breeding values for boars of the high testis weight (HTW) and low

\footnotetext{
${ }^{4}$ Purified LH (LER-786-3) was kindly furnished by Dr. L. E. Reichert, Jr., Dept. of Biochem., Emory Univ., Atlanta, GA.

${ }^{5}$ Antiporcine LH (no. 566) serum was kindly furnished by Dr. G. D. Niswender, Dept. of Physiol. and Biophys., Colorado State Univ., Fort Collins.

${ }^{6}$ Antiporcine FSH serum (USDA-10-1010) and purified FSH (USDA-FSH-PPI) were kindly furnished by Dr. D. J. Bolt, Animal Science Institute, Beltsville, MD.
}

testis weight (LTW) groups were 30.8 and $-32.9 \mathrm{~g}$, respectively.

Testis weight (TW) of male ancestors was predicted from measurements of in situ paired testis width (TWH) and testis length (TL) made at 140 and $160 \mathrm{~d}$ of age. The prediction equation used was: $\mathrm{TW}, \mathrm{g}=-508.3+12.5$ (TWH140) $+20($ TL140) $+16($ TWH160) +32 (TL160). The calculated multiple correlation between predicted TW and the average testis weight at 140 and $160 \mathrm{~d}$ was .92 .

Boars were born in two groups that were approximately 2 wk apart. They were weaned at 4 wk of age and placed in a nursery. At approximately 10 wk of age, boars were moved to a modified-open-front (MOF) finishing unit and penned in groups of nine. They were exposed to continuous lighting in the nursery and to natural October to December daylight in the MOF unit. Ad libitum feeding was practiced.

Blood samples were taken via jugular venipuncture at $42,56,70,84,98,112,126$ and $140 \mathrm{~d}$ of age. At each age, nine blood samples/ boar were taken at approximately $30-\mathrm{min}$ intervals. Blood samples were allowed to clot for approximately $24 \mathrm{~h}$ at $4 \mathrm{C}$ and then were centrifuged at $2000 \times \mathrm{g}$ for $30 \mathrm{~min}$. The serum fraction was decanted and stored at $-20 \mathrm{C}$. Luteinizing hormone was quantified for individual samples. A composite was made from the samples that were collected each day from each boar. Testosterone $(T)$, estradiol-17 $\beta\left(\mathbf{E}_{2}\right)$ and FSH concentrations were quantified on the pooled samples.

Concentrations of serum LH were determined in duplicate $300-\mu \mathrm{l}$ aliquots by a double antibody radioimmunoassay (RIA) described by Niswender et al. (1970). Purified LH (LER786-3 $)^{4}$ was used as a standard and for iodination. The LH was labeled by the chloramine $\mathrm{T}$ method (Greenwood et al., 1963) and isolated by column chromatography. Anti-porcine LH (no. 566) $)^{5}$ was utilized as the first antibody. Intra- and interassay coefficients of variation averaged 5.5 and $6.5 \%$, respectively.

Concentrations of serum FSH were determined in duplicate $250-\mu \mathrm{l}$ samples by the procedures of Bolt et al. (1981). Anti-porcine FSH (USDA-10-1010) ${ }^{6}$ was utilized as the first antibody and a second antibody was utilized to separate bound from free hormone. Purified FSH for iodination and standards was USDAFSH-PPI ${ }^{6}$. Duplicate assays of 125,250 and $500 \mu \mathrm{l}$ were parallel to the standard curve. First samples were estimated to contain $1,400,1,184$ 
and $1,359 \mathrm{pg} / \mathrm{ml}$ and second samples were estimated to contain $1,637,1,316$ and 1,114 $\mathrm{pg} / \mathrm{ml}$, respectively. Intra- and interassay coefficients of variation were 4.8 and $9.1 \%$, respectively.

Serum $E_{2}$ concentrations were determined using the procedures described by Britt et al. (1974) with double antibody separation of bound and free estradiol. The $\mathrm{E}_{2}$ antisera (Lilly no. 22673$)^{\gamma}$ specificity has been reported by Kesler et al. (1977). Recovery of added $\left[{ }^{3} \mathrm{H}\right]$ $\mathrm{E}_{2}$ averaged $89 \%$ and sample values were corrected for procedural loss. Duplicate 500- $\mu \mathrm{l}$ pooled serum samples were extracted with $4 \mathrm{ml}$ dimethylene chloride. Recovery of added mass $(10,25,50$ and $75 \mathrm{pg}$ estradiol) from $500 \mu \mathrm{l}$ of porcine plasma (ovariectomized gilt, $4.2 \mathrm{pg} / \mathrm{ml}$ estradiol) was $106 \pm 2 \%$. Assay determinations of $300,500,800,1,000$ and $1,400 \mu l$ of sample volume were parallel to the standard curve and contained $56.5,57.3,55.2,53.3$ and $52.0 \mathrm{pg}$ $\mathrm{E}_{2} / \mathrm{ml}$, respectively. Intra- and interassay coefficients of variation were 5.5 and $5.8 \%$, respectively.

Concentrations of $\mathrm{T}$ were determined in duplicate $100-\mu \mathrm{l}$ aliquots of serum by double antibody RIA as described by Kiser et al. (1978) utilizing a rabbit antiserum (MSU no. $\mathbf{7 4}^{8}$ prepared against testosterone-3-oximehuman serum albumin. Recovery of testosterone from the samples with $2 \mathrm{ml}$ of benzene-hexane averaged $89 \%$ and estimates were corrected for procedural loss. Standard curves for $T^{9}$ ranged from 37.5 to $2,400 \mathrm{pg}$ /tube. Recovery of added mass (125, 250 and 625 pg testosterone from $100 \mu \mathrm{l}$ of serum averaged $85 \pm 3 \%$. Assay determinations of 25 and $50 \mu \mathrm{l}$ of sample from each of four independent samples were highly correlated $(r=.99)$. Intra- and interassay coefficients of variation were 6.8 and $5.9 \%$, respectively.

Measurements of TWH, TL and body weight were taken at 98,112,126 and $140 \mathrm{~d}$ of age. Backfat probe was measured at $140 \mathrm{~d}$ of age and adjusted using body weight as a covariable. The boars were anesthetized with sodium thiamyl and castrated. The testes were wrapped

\footnotetext{
${ }^{7}$ Rabbit antiserum (Lilly no. 22673) against estradiol-6-BSA was kindly furnished by Dr. Norman Mason, Eli Lilly Co., Greenfield, IN.

${ }^{8}$ Rabbit antiserum (MSU no. 74) was kindly provided by Dr. E. M. Convey, Dept. of Anim. Sci., Michigan State Univ., East Lansing.

${ }^{9}$ Sigma Chemical Co., St. Louis, MO.
}

in plastic bags and placed on ice until weights were determined ( 2 to $4 \mathrm{~h}$ ). Individual testis and epididymis weights from each side of each boar were added together for analyses.

Immediately after the testes were weighed, two wedges of tissue were taken from the left testis of each boar. The tissue samples were fixed for $24 \mathrm{~h}$ in Bouins solution and then transferred to $70 \%$ ethanol. Fixed tissues were embedded in paraffin wax, and $5-\mu \mathrm{m}$ sections were stained with hematoxylineosin. Mean seminiferous tubule diameter was calculated from the measurement of 40 round tubules/boar (2.0 tubules/tissue sample). The percentage of tubules with a lumen and with active spermatogenesis (presence of spermatids) was estimated from the evaluation of 100 tubules/boar (50 tubules/tissue sample).

Statistical analyses were performed by general linear models procedures (SAS, 1979). In situ testis measurements (width and length) and hormone concentrations [T, $\mathrm{E}_{2}, \mathrm{FSH}$ and $\mathrm{LH}$ (mean of nine samples/d)] were fitted to a model that included the effects of line (L), farrowing group $(F), L \times F$, boar within $L \times F$, age (A), $A \times L$ and $A \times F$. Litter within $L$ $X F$ was not significant in initial analyses and -was deleted. Degrees of freedom and sums of squares for age effects were partitioned into linear, quadratic, cubic and lack of fit. Interactions of age with line and farrowing group were partitioned similarly. Line and farrowing group effects were tested with the boar within $\mathrm{L} \times \mathrm{F}$ mean square. The effects of $\mathrm{A}, \mathrm{A} \times \mathrm{L}$ and $\mathrm{A} \times \mathrm{F}$ were tested with the residual mean square.

Hormone concentrations, but not testis measurements, were fitted to periodic regressions (Bliss, 1970). These models included the effects of $L, F, L \times F$, boar within $L \times F$ plus the regressions on the first to third order Fourier terms. First order terms were cosin $(2 \pi t / 8)$ and $\sin (2 \pi t / 8)$, second order terms were $\operatorname{cosin}(2 \pi t / 4)$ and $\sin (2 \pi t / 4)$ and third order terms were cosin $(2 \pi t / 2.67)$ and $\sin$ $(2 \pi t / 2.67)$. First order terms fit single phase cosin and sin curves over the eighth measurement ages. Second order terms evaluate the biphasic cosin and sin curves and third order terms evaluate the triphasic curves. The value of $t$ is: (age at sampling -42)/14. This represents the order number $(0,1,2, \ldots 7)$ for a particular age. For each hormone, models were constructed to test the interaction of regression coefficients with $L$ and $F$. 
The fit of the data for each hormone to the general linear model and to the periodic regression model was compared. The periodic regression analysis gave the best fit $\left(\mathrm{R}^{2}=.67\right.$ vs $\mathrm{R}^{2}=$ .41) for LH concentration only. For LH concentration, regressions on third order terms and on the second order sin term were not significant. Interactions of regression coefficients $x$ boar within line-farrowing group were significant for both first order Fourier terms, but regressions on the second order cosin term did not interact with other effects. Thus, the final model for $\mathrm{LH}$ included the effects of $L, F, L \times F$, boar within $L \times F$, the within boar regressions on first order Fourier terms and the pooled regression on the second order cosin term. This model was used to plot the LH response over age and to generate a unique response curve for each boar. The maximum $\mathrm{LH}$ concentration and the age at maximum concentration were calculated for each boar. These were treated as new variables and fitted to a model that included the effects of $L, F$ and $L \times F$.

Tests for homogeneity of variance found that the variance of concentrations of all hormones were heterogeneous across ages, but were homogeneous across lines within ages. Thus, least-squares means were generated, and lines compared, from within age analyses of hormone concentrations. The model included the effects of $L, F$ and $L \times F$.

Differences in testicular development could be partially due to differences in body weight. To evaluate this possibility, $140-\mathrm{d}$ measurements of TWH, TL, epididymis weight, TW and backfat probe were fitted to a model that included the effects of $L, F, L \times F$ and the pooled regression on body weight. Testis width and TL data from each age were also fitted to a model that included the effects of $L, F, L \times F$, boar within $\mathrm{L} \times \mathrm{F}$ and the pooled within boar linear and quadratic regressions on body weight.

To evaluate line differences for steroid production relative to testis size, concentrations of $E_{2}$ and $T$ at $98,112,126$, and $140 \mathrm{~d}$ of age were fitted to a model that included the effects of $\mathrm{L}, \mathrm{F}, \mathrm{L} \times \mathrm{F}$ and the pooled regressions on TWH and TL. In addition, $T$ and $E_{2}$ concentrations at $140 \mathrm{~d}$ were fitted to a model including the effects of $\mathrm{L}, \mathrm{F}, \mathrm{L} \times \mathrm{F}$ and the pooled regression on TW.

Statistics to evaluate the variance of within boar and day LH samples were also examined. The distribution of within boar-age LH concen- trations was not significantly different from a normal distribution (Kolomogorov D Statistic, SAS, 1979). Thus, the pooled within boar-age sample variance is deemed to be a valid measure of the dispersion of samples for each boar. Homogeneity of the pooled within line variances was tested with an $F$ test of the ratio of variances.

Number of LH peaks exhibited by each boar was also estimated. A peak was defined as a sample whose lower $66 \%$ confidence limit was significantly higher than the upper $66 \%$ confidence limit for the immediately preceding and subsequent samples. The probability of determining a peak, when in fact the three samples have the same mean, is less than .005. The number of LH peaks was fitted to a model including the effects of $\mathrm{L}, \mathrm{F}$ and $\mathrm{L} \times \mathrm{F}$.

\section{Results}

Farrowing group was a significant source of variation for most of the traits studied. Boars of the second farrowing group grew more slowly, had smaller testis measurements and had lower hormone concentrations than did boars of the first farrowing group. The interaction of farrowing group $\times$ line was significant for only a few of the traits. These interactions were always a change in magnitude of differences and not a change in rank.

Least-squares means for body weight, backfat probe and in situ testis measurements are presented in table 1 . Boars with HTW were heavier $(\mathrm{P}<.05)$ than boars with LTW from 98 to $140 \mathrm{~d}$ of age. They also had higher $(\mathrm{P}<.01)$ adjusted backfat probes and in situ testis measurements. The advantage for boars with HTW for both TWH and TL was about 1 $\mathrm{cm}$ at each age. After adjustment for body weight using the between boar regressions at each age, the in situ testis measurements were from .8 to $.9 \mathrm{~cm}$ higher for boars with HTW. Adjustment of in situ testis measurements to the overall mean body weight $(52.5 \mathrm{~kg})$ using the pooled within boar regressions resulted in .53 and $.57 \mathrm{~cm}$ larger TWH and TL measurements, respectively, for boars with HTW.

Least-squares means for 140 -d excised testis traits are presented in table 2 . Boars with HTW had heavier testes and epididymides $(\mathrm{P}<.01)$ than did boars with LTW. Adjustment for body weight reduced the line differences in testis and epididymis weight only slightly. Boars with HTW had a larger percentage of tubules in which spermatogenesis was present, a larger 
TABLE 1. LEAST-SQUARES MEANS FOR IN SITU MEASUREMENTS ON BOARS WITH HIGH TESTIS WEIGHT (HTW) AND LOW TESTIS WEIGHT (LTW)

\begin{tabular}{|c|c|c|c|c|}
\hline \multirow{3}{*}{$\frac{\text { Trait }}{\text { Body weight }{ }^{\mathrm{a}}, \mathrm{kg}}$} & \multirow{2}{*}{$\begin{array}{c}\text { Age, d } \\
28 \\
98\end{array}$} & \multirow{2}{*}{$\frac{\text { HTW }}{\text { Mean } \pm S E}$} & \multirow{2}{*}{$\frac{\text { LTW }}{\text { Mean } \pm S E}$} & \multirow{2}{*}{$\begin{array}{l}\text { Significance } \\
\text { levelc }\end{array}$} \\
\hline & & & & \\
\hline & $\begin{array}{r}28 \\
98 \\
112 \\
126 \\
140\end{array}$ & $\begin{aligned} 6.3 & \pm .3 \\
39.3 & \pm 1.2 \\
49.9 & \pm 1.4 \\
59.2 & \pm 1.5 \\
68.2 & \pm 1.8\end{aligned}$ & $\begin{aligned} 6.4 & \pm .3 \\
35.0 & \pm 1.4 \\
44.2 & \pm 1.5 \\
54.4 & \pm 1.7 \\
61.5 & \pm 2.0\end{aligned}$ & $\begin{array}{l}* \\
* * \\
*\end{array}$ \\
\hline Backfat probe, mm & 140 & $16.8 \pm .40$ & $13.6 \pm .44$ & ** \\
\hline Testes width ${ }^{b}, \mathrm{~cm}$ & $\begin{array}{r}98 \\
112 \\
126 \\
140\end{array}$ & $\begin{array}{r}6.81 \pm .10 \\
7.92 \pm .12 \\
8.85 \pm .11 \\
10.12 \pm .14\end{array}$ & $\begin{array}{l}5.91 \pm .11 \\
6.88 \pm .14 \\
7.88 \pm .12 \\
9.15 \pm .15\end{array}$ & $\begin{array}{l}* * \\
* * \\
* * \\
* *\end{array}$ \\
\hline Testis length ${ }^{b}, \mathrm{~cm}$ & $\begin{array}{r}98 \\
112 \\
126 \\
140\end{array}$ & $\begin{array}{r}7.23 \pm .11 \\
8.37 \pm .13 \\
9.26 \pm .14 \\
10.72 \pm .16\end{array}$ & $\begin{array}{l}6.21 \pm .12 \\
7.18 \pm .14 \\
8.30 \pm .16 \\
9.63 \pm .18\end{array}$ & $\begin{array}{l}* * \\
* * \\
* * \\
* *\end{array}$ \\
\hline
\end{tabular}

${ }^{a}$ Effects $(P<, 05)$ include line, farrowing group, age linear, age quadratic, age linear $X$ line and age linear $X$ farrowing group.

${ }^{\mathrm{b}}$ Effects $(\mathrm{P}<.05)$ include line, farrowing group and age linear.

${ }^{c}$ Observed significance level for difference berween line means at each age.

$* \mathrm{P}<.05$.

${ }^{* *} \mathrm{P}<.01$.

TABLE 2. LEAST-SQUARES MEANS FOR 140-D EXCISED TESTIS TRAITS OF BOARS WITH HIGH TESTIS WEIGHT (HTW) AND LOW TESTIS WEIGHT (LTW)

\begin{tabular}{|c|c|c|c|}
\hline Trait $^{\mathbf{a}}$ & $\frac{\text { HTW }}{\text { Mean } \pm \text { SE }}$ & $\frac{\text { LTW }}{\text { Mean } \pm \text { SE }}$ & $\begin{array}{l}\text { Significance } \\
\text { level }^{b}\end{array}$ \\
\hline $\begin{array}{l}\text { TW, } g \\
\text { Adj. TW, g }\end{array}$ & $\begin{array}{l}240.4 \pm 13.0 \\
238.2 \pm 12.6\end{array}$ & $\begin{array}{l}173.2 \pm 14.3 \\
177.5 \pm 14.0\end{array}$ & $* *$ \\
\hline $\begin{array}{l}\text { EW, } g \\
\text { Adj. EW, } g\end{array}$ & $\begin{array}{l}49.8 \pm 2.3 \\
48.3 \pm 2.1\end{array}$ & $\begin{array}{l}39.6 \pm 2.6 \\
42.5 \pm 2.4\end{array}$ & $* *$ \\
\hline TUBDIA, $\mu \mathrm{m}$ & $116.7 \pm 3.6$ & $98.3 \pm 3.9$ & $* *$ \\
\hline SPERM, \% & $65.4 \pm 7.0$ & $40.3 \pm 7.7$ & $*$ \\
\hline LUMEN, \% & $74.2 \pm 5.1$ & $54.3 \pm 5.6$ & $*$ \\
\hline
\end{tabular}

\footnotetext{
${ }^{a_{T W}}=$ testes weight, Adj. TW = testes weight adjusted for body weight, EW = epididymides weight, Adj. $\mathrm{EW}=$ epididymides weight adjusted for body weight, TUBDIA = seminiferous tubule diameter, SPERM = percentage of seminiferous tubules with active spermatogenesis, LUMEN = percentage of seminiferous tubules with a lumen.

${ }^{\mathrm{b}}$ Observed significance level for difference between line means.

${ }^{\dagger} \mathbf{P}<10$.

" $\mathrm{P}<.05$.

** $\mathrm{P}<.01$.
} 


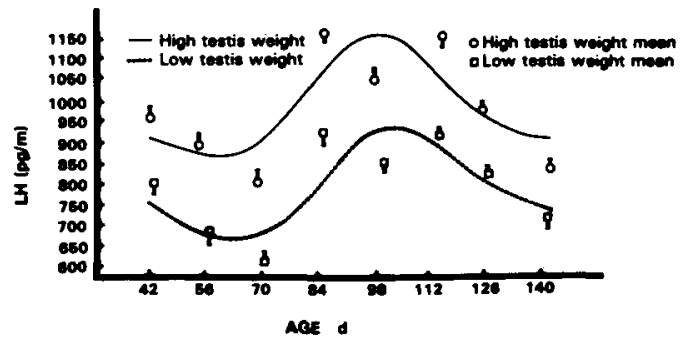

Figure 1. Mean (squares and circles) serum concentrations of luteinizing hormone (LH) and response predicted at each age by regression analysis (solid and broken lines) for boars with high and low testis weight.

percentage of tubules with a lumen $(\mathrm{P}<.05)$ and had a larger mean diameter of the seminiferous tubules $(\mathrm{P}<.01)$ than did boars with LTW.

Concentrations of $\mathrm{LH}$ were fitted to periodic regression equations and the mean predicted values are presented in figure 1 . A significant pubertal rise in LH occurred between 70 and $126 \mathrm{~d}$ of age.

Least-squares means and pooled within boar and age variance for $\mathrm{LH}$ concentrations are presented in table 3. Concentrations of LH were significantly higher for boars with HTW at all ages. Boars with HTW reached higher maximum predicted LH concentrations and had larger sample variances $(P<.01)$ than did boars with LTW. Although the difference was not significant, boars with HTW had predicted maximum LH concentrations at younger ages than did boars with LTW.

Least-squares means for FSH concentration are presented in table 4 and the corresponding response curve is in figure 2 . The two lines had similar FSH concentrations at each age. There was a cubic increase with age in serum FSH concentrations. Values of FSH changed little from 42 to $70 \mathrm{~d}$, increased rapidly from 84 to

TABLE 3. LEAST-SQUARES MEANS AND SAMPLE VARIANCE ESTIMATES FOR LUTEINIZING HORMONE CONCENTRATIONS OF BOARS WITH HIGH TESTIS WEIGHT (HTW) AND LOW TESTIS WEIGHT (LTW)

\begin{tabular}{lcccc}
\hline & HTW & LTW & Significance \\
Trait & Mean $\pm \mathrm{SE}$ & Mean $\pm \mathrm{SE}$ & \\
\hline levele
\end{tabular}

\footnotetext{
${ }^{a}$ Maximum concentration is the mean of the maximum predicted concentration of luteinizing hormone achieved by each boar from 42 to $140 \mathrm{~d}$ of age.

${ }^{b}$ Age at maximum is the mean age at which boars achieved maximum predicted concentrations.

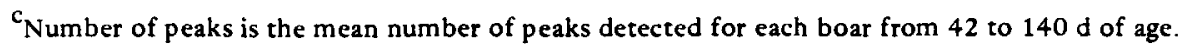

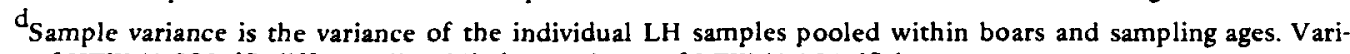
ance of HTW $(1,280 \mathrm{df})$ different $(\mathrm{P}<.01)$ than variance of LTW $(1,024 \mathrm{df})$ boars.

'Observed significance level for line difference at each age.

$* \mathrm{P}<.05$.

${ }^{* *} \mathrm{P}<.01$.
} 
TABLE 4. LEAST-SQUARES MEANS FOR FOLLICLE-STIMULATING HORMONE (PG/ML)a CONCENTRATIONS FOR BOARS WITH HIGH TESTIS WEIGHT (HTW) AND LOW TESTIS WEIGHT (LTW)

\begin{tabular}{|c|c|c|}
\hline & HTW & LTW \\
\hline Age, $d$ & Mean $\pm \mathrm{SE}$ & Mean $\pm \mathrm{SE}$ \\
\hline 42 & $1,724 \pm 138$ & $1,559 \pm 153$ \\
\hline 56 & $1,593 \pm 175$ & $1,547 \pm 186$ \\
\hline 70 & $1,564 \pm 184$ & $1,746 \pm 196$ \\
\hline 84 & $1,965 \pm 174$ & $1,933 \pm 193$ \\
\hline 98 & $5,291 \pm 139$ & $5,045 \pm 153$ \\
\hline 112 & $6,285 \pm 210$ & $6,100 \pm 232$ \\
\hline 126 & $6,167 \pm 206$ & $6,180 \pm 227$ \\
\hline 140 & $6,416 \pm 219$ & $6,163 \pm 241$ \\
\hline Overall mean & $3,873 \pm .115$ & $3,669 \pm 123$ \\
\hline
\end{tabular}

${ }^{a}$ Effects $(P<.05)$ include age linear, age quadratic and age cubic.

$98 \mathrm{~d}$ and again were similar from 112 to $140 \mathrm{~d}$ of age.

Least-squares means for $T$ concentrations are presented in table 5 and the response curve is in figure 3. There was a cubic increase in serum $T$ concentrations with age and $T$ concentrations tended to be higher $(\mathrm{P}<.10)$ for boars with HTW than for boars with LTW.

Least-squares means for $\mathrm{E}_{2}$ are presented in table 6 and the corresponding response curve is presented in figure 4 . There was a cubic increase in $E_{2}$ concentrations with age. Overall, $E_{2}$ concentrations were $(\mathrm{P}<.01)$ higher for boars with HTW and differences between boars with HTW and LTW were larger at older ages.

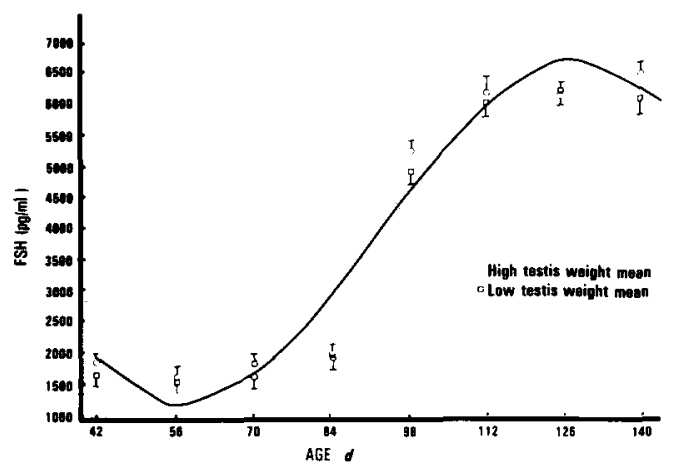

Figure 2. Mean (squares and circles) serum concentrations of follicle-stimulating hormone (FSH) and average response predicted at each age by regression analysis for boars with high and low testis weight.
Least-squares means for $\mathrm{T}$ and $\mathrm{E}_{2}$ concentrations adjusted for either testis width and length or excised testis weight are presented in table 7. After adjustment to a constant testis size, $\mathrm{T}$ concentrations for boars with HTW were slightly lower at 98 to $126 \mathrm{~d}$ of age but were greater at $140 \mathrm{~d}$ than $\mathrm{T}$ concentrations for boars with LTW. When adjusted to a constant testis size, $\mathrm{E}_{2}$ concentrations were not significantly different between boars with HTW and LTW.

\section{Discussion}

Testis size responded to selection pressure. The observed TW difference between boars with HTW and LTW (67.2 g at $140 \mathrm{~d}$ ) was close to the predicted difference $(64.0 \mathrm{~g}$ at $150 \mathrm{~d})$ assuming a heritability of .5 . Other researchers have also found testis size to be a moderately heritable trait in swine (Legault et al., 1980), mice (Islam et al., 1976), sheep (Land and Lee, 1976) and cattle (Coulter et al., 1976).

The consistent advantage in testis width and length at ages from 98 to $140 \mathrm{~d}$ for boars with HTW suggests that the line differences in testis size are better explained by a shift in the testis growth curve than by a change in the shape of the curve. No attempt was made to investigate the relationship of testis size and age of initiation of pubertal development. However, it seems likely that selection for increased testis size may have reduced the age at which pubertal development was initiated. No data were collected beyond $140 \mathrm{~d}$ of age and the results do not rule out the possibility that mature testis size and spermatogenic activity of LTW boars could equal that of HTW boars.

The majority of the differences in testis size between boars with HTW and LTW were independent of body weight. Adjusting either the in situ measurements or excised testis weights for body weight at a constant age reduced differences by less than $20 \%$. Adjustment of the TWH and TL measurements by within boar regressions on body weight suggest that about $42 \%$ of the differences were related to weight.

Boars with HTW had higher backfat probes than did boars with LTW. Other researchers have also found a similar relationship between measures of body composition and testicular development. Selection for increased lean growth rate in swine reduced testis weights and delayed sexual maturation when measured from 120 to $160 \mathrm{~d}$ of age (Schinckel et al., 1983). 
TABLE 5. LEAST-SQUARES MEANS FOR TESTOSTERONE (NG/ML)ª OF BOARS WITH HIGH TESTIS WEIGHT (HTW) AND LOW TESTIS WEIGHT (LTW)

\begin{tabular}{|c|c|c|c|}
\hline & HTW & LTW & Significance \\
\hline Age, $d$ & Mean $\pm \mathrm{SE}$ & Mean $\pm \mathrm{SE}$ & levelb \\
\hline 42 & $2.45 \pm .21$ & $2.33 \pm .24$ & \\
\hline 56 & $4.01 \pm .41$ & $2.84 \pm .44$ & $t$ \\
\hline 70 & $4.81 \pm .43$ & $3.31 \pm .45$ & * \\
\hline 84 & $5.60 \pm .53$ & $4.69 \pm .59$ & \\
\hline 98 & $6.31 \pm .60$ & $6.19 \pm .66$ & \\
\hline 112 & $8.10 \pm .58$ & $7.76 \pm .64$ & \\
\hline 126 & $9.24 \pm .43$ & $9.87 \pm .60$ & \\
\hline 140 & $13.77 \pm .62$ & $12.05 \pm .68$ & $t$ \\
\hline Overall mean & $6.79 \pm .31$ & $5.90 \pm .34$ & $t$ \\
\hline
\end{tabular}

${ }^{\mathrm{a}}$ Effects included line, farrowing group, age linear, age quadratic and age cubic. $\mathrm{P}<.10$ for line, $\mathrm{P}<.05$ for the remaining effects.

${ }^{b}$ Observed significance level for difference between line means at each age.

${ }^{\dagger} \mathbf{P}<10$.

$* \mathrm{P}<.05$.

Selection for efficiency of lean growth in rats decreased testis weight at $85 \mathrm{~d}$ of age (Allrich et al., 1981). Although Andresen (1976) did not record testis weights, higher levels of $5 \alpha$ androstenone and testosterone were found in the systemic plasma of boars selected for fatness and low rate of gain than in boars selected for low backfat thickness and high rate of gain. These results suggest a relationship between carcass and sexual maturation. One current theory is that mammals must reach a particular ratio of fat to lean or body fat to weight before normal sexual maturation occurs (Frish, 1980).

Selection for testis size may have changed endocrine function such that boars with HTW

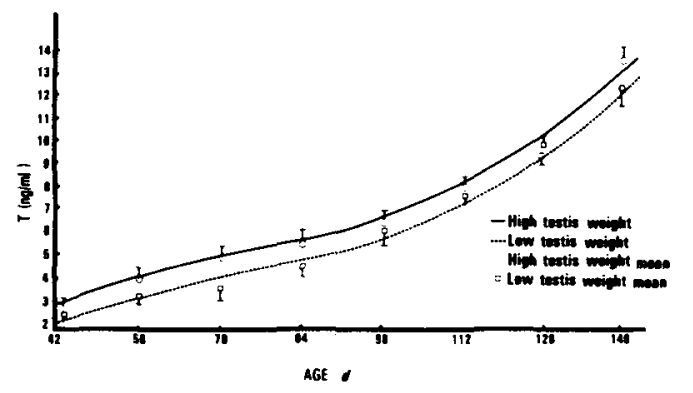

Figure 3. Mean (squares and circles) serum concentrations of testosterone $(T)$ and response predicted at each age by regression analysis (solid and broken lines) for boars with high and low testis weight. were less sensitive to the suppressive effects of gonadal steroids or that the testes of boars with HTW were producing less steroid relative to testis size. Boars with HTW had higher LH concentrations while maintaining higher levels of $E_{2}$ than boars with LTW. They also had

TABLE 6. LEAST-SQUARES MEANS FOR ESTRADIOL-17 $\beta$ (PG/ML)a OF BOARS WITH HIGH TESTIS WEIGHT (HTW) AND LOW TESTIS WEIGHT (LTW)

\begin{tabular}{|c|c|c|c|}
\hline \multirow[b]{2}{*}{ Age, d } & \multirow{2}{*}{$\frac{\mathrm{HTW}}{\text { Mean } \pm \mathrm{SE}}$} & \multirow{2}{*}{$\frac{\text { LTW }}{\text { Mean } \pm S E}$} & \multirow{2}{*}{$\begin{array}{l}\text { Significance } \\
\text { levelb }\end{array}$} \\
\hline & & & \\
\hline 42 & $15.4 \pm 1.3$ & $12.6 \pm 1.4$ & \\
\hline 56 & $13.3 \pm 1.3$ & $12.4 \pm 1.4$ & \\
\hline 70 & $15.3 \pm 1.1$ & $12.0 \pm 1.2$ & * \\
\hline 84 & $14.1 \pm 1.1$ & $11.2 \pm 1.3$ & $t$ \\
\hline 98 & $24.4 \pm 1.8$ & $19.6 \pm 2.0$ & $t$ \\
\hline 112 & $25.6 \pm 2.6$ & $22.7 \pm 2.9$ & \\
\hline 126 & $32.2 \pm 2.5$ & $24.8 \pm 2.8$ & $*$ \\
\hline 140 & $38.0 \pm 2.3$ & $29.0 \pm 2.6$ & $* *$ \\
\hline
\end{tabular}

${ }^{\text {a Effects }}(P<.05)$ include line, farrowing group, age linear, age linear $X$ treatment, age quadratic and age cubic.

${ }^{b}$ Observed significance level for difference between line means at each age.

$$
\begin{aligned}
& { }^{\dagger} \mathrm{P}<.10 . \\
& { }^{*} \mathrm{P}<.05 \\
& { }^{*} \mathrm{P}<.01 .
\end{aligned}
$$




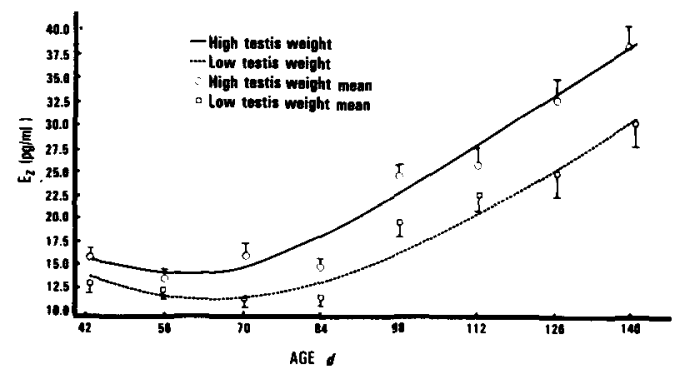

Figure 4. Mean (squares and circles) serum concentration of estradiol-17 $\beta\left(E_{2}\right)$ and response predicted at each age by regression analysis (solid and broken lines) for boars with high and low testis weight.

higher predicted maximum LH concentrations and tended to reach their maximum pubertal levels at younger ages. These results suggest the possibility that boars with HTW were less sensitive to negative feedback than boars with LTW.

After adjustment for differences in testis size, T concentrations of boars with HTW were slightly lower at 98 to $126 \mathrm{~d}$ of age. However, $\mathrm{T}$ concentrations at $140 \mathrm{~d}$ and overall $\mathrm{E}_{2}$ concentrations did not follow this trend.

Serum FSH concentrations for boars with HTW and LTW were not significantly different at any age. Follicle-stimulating hormone has a major role in female reprodution. There are a number of studies with mice in which changes from genetic selection for ovulation rate or litter size have been attributed to changes in circulating FSH levels or to changes in ovarian sensitivity to FSH (Bindon and Pennycuik, 1974; Wolfe et al., 1981). In the study reported herein, changes in testis size from genetic selection occurred without evident changes in serum FSH in the boar. Results suggest that the differences in spermatogenic and steroidogenic functions in testes of the HTW and LTW boars were too small to reflect differences in serum FSH concentrations.

The patterns of hormone concentrations observed in the present study were similar to previous reports. A significant elevation in $\mathrm{LH}$ concentrations occurred between 12 and 18 wk of age. FlorCruz and Lapwood (1978) reported that a significant elevation of LH occurred between 12 and 22 wk of age and that levels were maximum at $16 \mathrm{wk}$. However, Romanowicz et al. (1976) and Allrich et al. (1982) did not observe significant elevations in LH concentrations during this period. Serum LH during pubertal development may be partially responsible for growth of the testes and for increasing $\mathrm{T}$ concentrations. Pubertal rises in LH occurred before the period of most rapid testicular development in rams (Land and Carr, 1979),

TABLE 7. LEAST-SQUARES MEANS FOR TESTOSTERONE (T) AND ESTRADIOL-17 $\left(\mathrm{E}_{2}\right.$ ) CONCENTRATIONS, ADJUSTED FOR EITHER TESTIS WIDTH AND LENGTH OR EXCISED TESTIS WEIGHT, OF BOARS WITH HIGH TESTIS WEIGHT (HTW) AND LOW TESTIS WEIGHT (LTW)

\begin{tabular}{|c|c|c|c|c|}
\hline \multirow{2}{*}{$\frac{\text { Trait }}{\mathrm{T}^{\mathrm{a}}, \mathrm{ng} / \mathrm{ml}}$} & \multirow{2}{*}{$\frac{\text { Age, } d}{98}$} & \multirow{2}{*}{$\frac{\text { HTW }}{\text { Mean } \pm S E}$} & \multirow{2}{*}{$\frac{\text { LTW }}{\text { Mean } \pm \text { SE }}$} & \multirow{2}{*}{$\begin{array}{l}\text { Significance } \\
\text { levelc }^{c}\end{array}$} \\
\hline & & & & \\
\hline $\mathrm{T}^{\mathrm{a}}, \mathrm{ng} / \mathrm{ml}$ & $\begin{array}{r}98 \\
112 \\
126 \\
140\end{array}$ & $\begin{array}{r}5.67 \pm .67 \\
7.47 \pm .65 \\
8.63 \pm .60 \\
14.11 \pm .71\end{array}$ & $\begin{array}{r}7.13 \pm .82 \\
8.65 \pm .79 \\
10.81 \pm .73 \\
11.67 \pm .85\end{array}$ & $\begin{array}{l}t \\
t\end{array}$ \\
\hline $\mathrm{T}^{\mathrm{b}}, \mathrm{ng} / \mathrm{ml}$ & 140 & $13.33 \pm .56$ & $12.45 \pm .62$ & \\
\hline $\mathrm{E}_{2}{ }^{\mathrm{a}}, \mathrm{Pg} / \mathrm{ml}$ & $\begin{array}{r}98 \\
112 \\
126 \\
140\end{array}$ & $\begin{array}{l}21.9 \pm 2.0 \\
22.0 \pm 2.8 \\
30.4 \pm 2.9 \\
36.8 \pm 2.7\end{array}$ & $\begin{array}{l}23.2 \pm 2.4 \\
27.3 \pm 3.4 \\
27.3 \pm 3.5 \\
30.7 \pm 3.3\end{array}$ & \\
\hline $\mathrm{E}_{2} \mathrm{~b}, \mathrm{pg} / \mathrm{ml}$ & 140 & $36.0 \pm 2.4$ & $31.5 \pm 2.8$ & \\
\hline
\end{tabular}

\footnotetext{
${ }^{a}$ Adjusted for testes width and length.

${ }^{b}$ Adjusted for excised testis weight.

${ }^{c}$ Observed significance level for difference between line means at each age.

$t_{\mathrm{P}<\mathrm{10} \text {. }}$
} 
rats (Slob et al., 1980), bulls (Lacroix and Pelletier, 1979; McCarthy et al., 1979) and humans (August et al., 1972).

Concentrations of FSH increased rapidly from 70 to $112 \mathrm{~d}$ of age, with most of the increase occurring between 84 and $98 \mathrm{~d}$. Abrupt increases in FSH concentrations have been found in the rat immediately before the onset of spermatogenesis (Payne et al., 1977). In human males, FSH levels increased slowly from 6 to $12 \mathrm{yr}$ of age and rapid increases occurred from 12 to $17 \mathrm{yr}$ (Faimen and Winter, 1974).

Follicle-stimulating hormone has been implicated in the control of Leydig cell function because FSH increased testicular responsiveness to $\mathrm{LH}$ in immature rats and increased the number of $\mathrm{LH}$ receptors/testis (Sizonenko et al., 1977; Bartke et al., 1978). Also, FSH is involved at the Sertoli cell in the synthesis of $E_{2}$ from $T$ (Dorrington et al., 1978). With respect to these postulated functions, it is interesting that $\mathrm{T}, \mathrm{E}_{2}$ and $\mathrm{FSH}$ had parallel changes with respect to age in this study. Leydig cell maturation of boar testes coincides with the observed rise in FSH concentrations. Berardinelli et al. (1982) evaluated boars from 40 to $250 \mathrm{~d}$ of age and found specific binding of [ $\left.{ }^{125} \mathrm{I}-\right]$ hCG expressed/gram tissue weight was maximum at $100 \mathrm{~d}$ of age. The greatest $\mathrm{T}$ production capacity occurred at $160 \mathrm{~d}$ of age.

Concentrations of $\mathrm{T}$ increased with age in the present study. This pattern is similar to that previously reported (Andresen, 1976; Romanowicz et al., 1976; FlorCruz and Lapwood, 1978; Allrich et al., 1982). This increase in $\mathrm{T}$ was likely caused by the pubertal rise in $\mathrm{LH}$ and(or) greater responsiveness of the testis to gonadotropin during this time period.

Concentrations of $E_{2}$ fluctuated from 42 to $84 \mathrm{~d}$. of age and increased in a linear fashion thereafter. Allrich et al. (1982) found a similar pattern for $E_{2}$ concentrations.

The results suggest that testis size in boars will respond to selection and that genetic changes in testis size may be related to differences in male endocrine function. As originally suggested by Land (1973), selection for testis size may also lead to changes in female endocrine function and reproductive performance.

\section{Literature Cited}

Allrich, R. D., R. K. Christenson, J. J. Ford and D. R. Zimmerman. 1982. Pubertal development of the boar: Testosterone, estradiol-17 $\beta$, cortisol and
LH concentrations before and after castration at various ages. J. A nim. Sci. 55:1139.

Allrich, R. D., C. T. Wang, G. E. Dickerson and D. R. Zimmerman. 1981. Selection for increased rate or efficiency of lean growth in rats: Correlated changes in reproductive performance. J. Anim. Sci. 53:1458.

Andresen, O. 1976. Concentrations of fat and plasma $5 \alpha$-androstenone and plasma testosterone in boars selected for rate of body weight gain and thickness of backfat during growth, sexual maturation and after mating. J. Reprod. Fertil. 48:51.

August, G. P., M. M. Grumbach and S. L. Kaplan. 1972. Hormonal changes in puberty. III. Correlation of plasma testosterone, LH, FSH, testicular size and bone age with male pubertal development. J. Clin. Endocrinol. Metab. 34:319.

Bartke, A., A. A. Hafiez, F. J. Bex and S. Dalterio. 1978. Hormonal interactions in regulation of androgen secretion. Biol. Reprod. 18:44.

Berardinelli, J. G., R. D. Allrich and J. J. Ford. 1982. Characterization of LH-hCG receptor in testis of boars and its relationships with morphological and steroidogenic characteristics during development. J. Anim. Sci. 55(Suppl. 1): 339.

Bindon, B. M. and. P. R. Pennycuik. 1974. Differences in ovarian sensitivity of mice selected for fecundity. J. Reprod. Fertil. 36:221.

Bliss, C. I. 1970. Statistics in Biology, Vol. II. McGrawHill Book Co., New York.

Bolt, D. J., R. Rollins and H. D. Guthrie. 1981. Development of a porcine FSH radioimmunoassay. J. Anim. Sci. 53(Suppl. 1):298.

Britt, J. H., R. J. Kittok and D. S. Harrison. 1974. Ovulation, estrus and endocrine response after GnRH in early postpartum cows. J. Anim. Sci. 37:915.

Carr, W. R. and. R. B. Land. 1975. Plasma luteinizing hormone levels and testis diameter of ram lambs of different breeds. J. Reprod. Fertil. 42: 325 .

Coulter, G. H., T. R. Rounsaville and R. H. Foote. 1976. Heritability of testicular size and consistency in Holstein bulls. J. Anim. Sci. 43:9.

Dorrington, J. H., I. B. Fritz and D. T. Armstrong 1978. Control of testicular estrogen synthesis. Biol. Reprod. 18:55.

Faimen, C. and J.S.D. Winter. 1974. Gonadotropins and sex hormone patterns in puberty: Clinical data. In: M. M. Grumbach, D. D. Grave and F. E. Mayer (Ed.) The Control of the Onset of Puberty. J. Wiley and Sons, New York.

FlorCruz, S. V. and. K. R. Lapwood. 1978. A longitudinal study of pubertel development in boars. Int. J. Androl. 1:317.

Frish, R. E. 1980. Pubertal adipose tissue: Is it necessary for normal sexual matruation? Fed. Proc. 39:2395.

Greenwood, F. D., W. M. Hunter and J. S. Glover. 1963. The preparation of ${ }^{131}$ I-labeled human growth hormone of high specific radioactivity. Biochem. J. 89:114.

Hanrahan, J. P. and. J. F. Quirke. 1977. Testis size and plasma luteinizing hormones as aids to selection for fecundity in sheep. Anim. Prod. 24:148.

Islam, M.A.B.M., W. G. Hill and R. B. Land. 1976. 
Ovulation rate of lines of mice selected for testis weight. Genet. Res. 27:23.

Joakimsen, Q. and R. L. Baker. 1977. Selection for litter size in mice. Acta Agr. Scand. 27:301.

Kesler, D. J., H. A. Garverick, R. S. Youngquist, R. G. Elmore and C. J. Bierschwal. 1977. Effects of days postpartum and endogenous reproductive hormones on $\mathrm{GnRH}$-induced $\mathrm{LH}$ release in dairy cows. J. Anim. Sci. 45:797.

Kiser, T. E., R. A. Milvae, H. D. Hafs, W. D. Oxender and T. M. Louis. 1978. Comparison of testosterone and androstenedione secretion in bulls given prostaglandin $F_{2} \alpha$ or luteinizing hormone. J. Anim. Sci. 46:436.

Lacroix, A. and J. Pelletier. 1979. Short-term variations in plasma $\mathrm{LH}$ and testosterone in bull calves from birth to 1 year of age. J. Reprod. Fertil. 55:81.

Land, R. B. 1973. The expression of female sex-limited characters in the male. Nature 241:208.

Land, R. B. and. W. R. Carr. 1975. Testis growth and plasma LH concentration following hemicastration and its relationship with female prolificacy in sheep. J. Reprod. Fertil. 45:495.

Land, R. B. and. W. R. Carr. 1979. Reproduction in domestic mammals. In: J.G.M. Shire (Ed.) Genetic Variation in Hormone Systems. pp 89-111. CRC Press, New York.

Land, R. B. and. C. J. Lee. 1976. Testis growth, a possible genetic predictor of female reproductivity. Anim. Prod. 22:135 (Abstr.).

Legault, C., J. Gruand and F. Oulion. 1980. Development and genetic value of an in vivo method of estimating testis weight in young boars. Anim. Breed. 48:26 (Abstr.).

Lush, J. L. 1948. The genetics of a population. Mimeographed Lecture Notes. pp 309-311.
McCarthy, M. S., E. M. Convey and H. D. Hafs. 1979. Serum hormonal changes and testicular response to LH during puberty in bulls. Biol. Reprod. 20: 1221 .

Niswender, G. D., L. E. Reichert, Jr. and D. R. Zimmerman. 1970. Radioimmunoassay of serum levels of LH throughout the estrous cycle in pigs. J. Endocrinol. 87:576.

Payne, A. H., R. P. Kelchm, E. P. Murono and J. T. Kalan. 1977. Hypothalamic, pituitary and testicular function during sexual maturation of the male rat. J. Endocrinol. 72:17.

Romanowicz, D., R. Stupnicki, B. Barcikowski, A. Madej and M. Welch. 1976. Plasma testosterone and LH in growing boars. Proc. VIIIth Int. Congress Anim. Reprod. A.I., Cracow.

SAS. 1979. SAS User's Guide. Statistical Analysis System Institute, Inc., Cary, NC.

Schnickel, A., R. K. Johnson, R. A. Pumfrey and D. R. Zimmerman. 1983. Testicular growth of different genetic lines and its relationship to reproductive performance. J. Anim. Sci. 56:1065.

Sizonenko, P. C., R. Rappaport, N. Josso and F. Dray. 1977. FSH. II. Evidence for its mediating role on testosterone secretion in hypopituitarism. Acta Endocrinol. 84:390.

Slob, A. K., M. P. Ooms and J.T.M. Vreeburg. 1980. Prenatal and early postnatal sex differences in plasma and gonadal testosterone and plasma luteinizing hormone in female and male rats. $J$. Endocrinol. 87:81.

Wolfe, H. G., A. Bartke, A. Amador, M. van Sickel, S. Dalterio and D. Brown. 1981. Testicular function in strains of mice selected for differences in gonadotrophin-induced ovulation rate. J. Endocrinol. 90:367. 